\title{
Preparation of shotcrete coarse aggregate with low grade clay and coal ash
}

\author{
Kyung Nam Kim, Hee Su Jung and Hyun Park ${ }^{\dagger}$ \\ Department of Advanced Materials Engineering, Kangwon National University, Samcheok 245-711, Korea
}

(Received March 2, 2010)

(Revised March 31, 2010)

(Accepted April 30, 2010)

\begin{abstract}
In this study, the artificial coarse aggregate was manufactured by using coal ash and low grade clay. The characteristics of a coal ash-clay system were investigated using XRD, XRF, TG-DTA, SEM and Dilatometer with various coal ash contents. The chemical compositions are the fly ash, bottom ash and clay, $\mathrm{Al}_{2} \mathrm{O}_{3}$ are $28.5 \mathrm{wt} \%, 32.4 \mathrm{wt} \%$ and $18.1 \mathrm{wt} \%$, and $\mathrm{SiO}_{2}$ are $33.0 \mathrm{wt} \%, 53.7 \mathrm{wt} \%$ and $68.4 \mathrm{wt} \%$ in weight ratio, respectively. The shrinkage of specimens started at around $850^{\circ} \mathrm{C}$ and changed little up to $1100^{\circ} \mathrm{C}$, but increased markedly at above $1100^{\circ} \mathrm{C}$. The shrinkage rate is strongly related to the decarbonization amount of coal ash. At the sintering temperature $1150^{\circ} \mathrm{C}$, it was found that quartz, mullite, anorthite and albite phase exist in all specimens. It was found that bottom-clay system specimen sintered at $1150^{\circ} \mathrm{C}$ had a good compressive strength of $87.5 \mathrm{~kg} / \mathrm{cm}^{2}$, and the compressive strength of bottom-clay specimen was higher than that of fly-clay system specimen. The reusability of coal ash as a raw material in the process of shotcrete resources such as artifical coarse aggregate is highly expected.
\end{abstract}

Key words Clay, Coal ash, Aggregate, Shotcrete

\section{저급 점토와 석탄회를 이용한 솟크리트용 골재의 제조}

김경남, 정희수, 박현"

강원대학교 신소재공학과, 삼척, 245-711

(2010년 3월 2일 접수)

(2010년 3월 31일 심사완료)

(2010년 4월 30일 게재확정)

요 약 본 연구에서는 인공골재를 제조하기 위하여 저급 점토에 석탄회(Fly Ash와 Bottom Ash)를 각각 첨가하여, 여러 분석기기(SEM, XRD, XRF, TG-DTA, Dilatometer, UTM)를 이용하여 물리 · 화학적 특성을 조사하였다. Fly ash, bottom ash, clay의 화학조성은 $\mathrm{SiO}_{2}$ 가 33.01, 53.73 및 $68.36 \mathrm{wt} \% \mathrm{Al}_{2} \mathrm{O}_{3}$ 는 28.54, 32.42 및 $18.12 \mathrm{wt} \%$ 와 이외에 $\mathrm{Fe}_{2} \mathrm{O}_{3}$ 와 알카리 성분 등 이 함유하고 있다. 소성에 의한 인공골재의 치밀화 과정을 관찰하기 위해 Dilatometer를 측정하였다. 시편들은 $850^{\circ} \mathrm{C}$ 부근 에서 서서히 수축이 시작되어 $1100^{\circ} \mathrm{C}$ 부근에서 급격하게 수축하는 것을 볼 수 있었다. 소성온도와 배합조성에 따른 시편의 결정상을 알아보기 위하여 $1150^{\circ} \mathrm{C}$ 에서 30 분간 열처리 하였으며 fly Ash를 사용한 시편의 주 결정상은 quartz, anorthite, albite상이 관찰되었고 bottom ash를 사용한 시편은 quartz, anorthite, mullite가 관찰되었다. $1150^{\circ} \mathrm{C}$ 에서 소성한 시편에서 플 라이애쉬 보다 바탐애쉬를 첨가한 시편이 압축강도가 우수 하며, 바탐애쉬 첨가한 시편의 경우 압축강도 $87.5 \mathrm{kgf} / \mathrm{cm}^{2}$ 로 가 장 우수 하였으며 인공골재로의 이용이 가능함을 알 수가 있다.

\section{1. 서 론}

현재 산업화의 영향으로 에너지 수요가 급증함에 따라 세계적으로 매장량이 풍부하고, 가격이 저렴하며 공급원

\footnotetext{
Corresponding author

Tel: +82-33-570-6564

Fax: +82-33-570-6557

E-mail: hipark@kangwon.ac.kr
}

이 안정된 석탄의 수요는 꾸준히 증가시키고 있다. 그러 나 화력발전소에 사용된 석탄은 부산물로 coal ash(석탄 회)를 발생 시키는데, 2010년에는 약 600만톤까지 증가 할 것으로 예상된다 $[1,2]$. 화력발전소에서 생성되는 coal $\mathrm{ash}$ 는 보통 바닥재인 bottom ash(저회)와 비산재인 fly $\mathrm{ash}$ (비회)로 구분되어진다. 화력발전소 로(爐) 내의 고온 영역인 수관, 과열기 및 재열기의 열 흡수 표면에 형성 된 slag가 자중(自重)에 의하여 낙하되거나, 급격한 출력 
변화, soot blowing에 의하여 로 하부로 낙하되어 bottom hopper에서 포집되는 ash를 bottom ash라고 한다. Fly ash는 보일러 로 내에서 미연탄소 연소시 ash 성분 입자 가 연소가스와 흐르면서 절탄기, 공기예열기 및 전기집 진기에서 포집되는 ash를 지칭한다. Bottom ash는 전체 ash 발생량의 약 20 40\% 정도이며 fly Ash는 전체량의 약 60 80\%에 이르고 있다[3].

Coal ash의 재활용을 위한 연구는 경제적, 부족한 자 원의 확보 차원과 최근 환경보존 문제라는 측면에서 매 우 중요시 되고 있어 coal ash가 선진국에서는 '제3의 자원'으로 고려되어지고 있다. 선진국에서는 석탄회의 재활용률이 $60 \%$ 로서 시멘트분야, 골재, 토목, 건축자재 등에 광범위하게 재활용되고 있다[2,4]. 현재 석탄회를 이용한 재료로서는 부피비중이 $0.10 \sim 0.13 \mathrm{~g} / \mathrm{cm}^{3}$ 인 내열 보온재로, $0.53 \sim 1.0 \mathrm{~g} / \mathrm{cm}^{3}$ 인 규산칼슘계 건축재료가 주류 를 이루고 있으며, 국내에서도 경량 골재 제조에 관한 연구가 진행되고 있으나 제조 방법 및 사용원료에 따라 $10 \sim 30 \%$ 의 높은 흡수율을 나타내어 2 차 제품으로 활용 하기에 어려움이 있다[5]. 따라서 재활용률이 $10 \%$ 정도 인 국내의 경우 석탄회의 재활용에 관한 연구가 절실히 요구되고 있다.

따라서, 본 연구에서는 기공률과 흡수율 및 압축강도 가 우수한 골재를 제조하여 숏크리트용에 응용하기 위하 여 저급 점토에 fly ash와 bottom ash를 각각 첨가하여 열처리 조건에 따른 물리 - 화학적 특성을 조사하고자 하 였다.

\section{2. 실험방법}

\section{1. 석탄회-점토계}

출발물질 원료는 강원도 $\mathrm{D}$ 화력발전소 유동층상 로의 fly ash, bottom ash와 강원 $\mathrm{S}$ 사의 저급 점토를 이용하 였으며, 실험의 조성비는 Table 1에 나타내었으며 석탄

Table 1

Mixing ratio of raw materials (Unit: wt\%)

\begin{tabular}{lllll}
\hline Sample & Fly ash & Bottom ash & Clay & Sintering temp. $\left({ }^{\circ} \mathrm{C}\right)$ \\
\hline FC28 & 20 & - & 80 & \\
FC37 & 30 & - & 70 & \\
FC46 & 40 & - & 60 & \\
FC55 & 50 & - & 50 & $1000,1100,1150$ \\
BC28 & - & 20 & 80 & \\
BC37 & - & 30 & 70 & \\
BC46 & - & 40 & 60 & \\
BC55 & - & 50 & 50 & \\
\hline
\end{tabular}

F: Fly ash, B: Bottom ash, C: Clay
회는 전처리 과정 없이 사용하였다. 석탄회-점토계는 fly ash-cly계(이하 FC) 와 bottom ash-clay계(이하 $\mathrm{BC}$ )를 $20: 80,30: 70,40: 60$ 및 $50: 50$ 의 $\mathrm{wt} \%$ 로 변화시켜 각각 제조하였다. 물리적 특성을 위해 각 시편은 1000 $\mathrm{psi}$ 의 압력으로 일축 가압하여 $\Phi 10 \times 12 \mathrm{~mm}$ 의 크기로 공시체를 제조한 후, 건조과정 없이 전기로를 이용하여 $7^{\circ} \mathrm{C} / \mathrm{min}$ 의 승온 속도로 $1,000,1,100,1150^{\circ} \mathrm{C}$ 에서 각각 30 분간 유지하여 냉각 하였다. 그리고 인공골재는 물/혼 합분말로 혼련한 후, $10 \sim 15 \mathrm{~mm}$ 의 구형으로 성형하여 건조과정 없이 자체 제작한 내경 $60 \mathrm{~mm}$, 길이 $1000 \mathrm{~mm}$ 의 로타리킬른(rotary kiln)을 이용하여 $1100^{\circ} \mathrm{C}$ 에서 급속 가열하여 제조하였다.

\section{2. 특성분석}

출발원료들의 화학적 성분을 분석하기 위하여 $\mathrm{X}$-선 형광 분석기(XRF, ZSX100e, Rigaku, Japan)를 이용하 여 분석하였다. 원료와 열처리 온도에 따른 결정상을 조 사하기 위하여 X-선 회절 분석기(XRD, D/Max-2200, Rigaku, Japan)를 이용하여 $\mathrm{CuK} \alpha, 30 \mathrm{kV}, 20 \mathrm{~mA}$ 의 조 건으로 측정하였다. 소성과정 중의 길이 변화를 열팽창 계수 측정기(Dilatometer, Unitherm medel-1161, Anter Corp., USA)를 이용하여 $7^{\circ} \mathrm{C} / \mathrm{min}$ 의 승온속도로 $1150^{\circ} \mathrm{C}$ 까지 측정하였다. 열처리 온도와 조성에 따른 시편의 물 리적 특성을 조사하기 위하여 KS F 2503에 따라 흡수 율을 측정하였으며, 압축강도는 KS L 3305에 따라 만 능시험기(UTM, 8801, INSTRON, USA)을 이용하여 $0.2 \mathrm{MPa}$ 의 속도로 하중을 측정하였으며 흡수율과 압축 강도에서 측정된 결과는 시편 5 개를 선택하여 평균값으 로 나타내었다[6,7]. 미세구조는 시편의 파단면에 $\mathrm{Au}$ 코 팅을 행한 후 주사전자현미경(SEM, JSM-5410, JEOL, Japan)을 이용하여 관찰하였다.

\section{3. 결과 및 고찰}

\section{1. 출발원료의 화학적 특성}

강원도 $\mathrm{D}$ 화력발전소의 석탄회와 강원 $\mathrm{S}$ 사 점토에 대 한 화학적 조성을 Table 2에 나타내었다.

$\mathrm{D}$ 화력발전소의 fly ash와 bottom ash는 화학조성이 $\mathrm{SiO}_{2}$ 가 $33.01 \mathrm{wt} \%, 53.73 \mathrm{wt} \%, \mathrm{Al}_{2} \mathrm{O}_{3}$ 가 $28.54 \mathrm{wt} \%, 32.42$ $\mathrm{wt} \%$ 이며 이외에 $\mathrm{Fe}_{2} \mathrm{O}_{3}$ 와 알칼리성분 등이 함유되어 있 다. 그리고 석탄회에서 $\mathrm{CaO}$ 함량이 bottom ash 보다는 fly ash에 많은 양이 함유되어 있었다. 일반적으로 석탄 회는 $\mathrm{Si}$ 와 $\mathrm{Al}$ 성분을 $80 \%$ 이상 함유하여 규산염광물 (aluminosilicate minerals)과 유사한 특성을 나타내며 
Table 2

Chemical composition of raw materials

\begin{tabular}{llllllllll}
\hline \multirow{2}{*}{ Raw materials } & \multicolumn{2}{l}{ Chemical components (wt\%) } \\
\cline { 2 - 10 } & $\mathrm{SiO}_{2}$ & $\mathrm{Al}_{2} \mathrm{O}_{3}$ & $\mathrm{CaO}$ & $\mathrm{MgO}$ & $\mathrm{SO}_{3}$ & $\mathrm{~K}_{2} \mathrm{O}$ & $\mathrm{Fe}_{2} \mathrm{O}_{3}$ & $\mathrm{Na}_{2} \mathrm{O}$ & $\mathrm{Ig}$. loss \\
\hline Fly ash & 33.01 & 28.54 & 9.97 & 0.77 & 2.43 & 3.32 & 1.47 & 0.23 & 20.26 \\
Bottom ash & 53.73 & 32.42 & 1.2 & 0.74 & 0.46 & 4.33 & 3.24 & 0.15 & 3.73 \\
Clay & 68.36 & 18.12 & 1.84 & 1.08 & 0.03 & 6.17 & 0.78 & 0.14 & 3.48 \\
\hline
\end{tabular}

$\mathrm{Ca}, \mathrm{Mg}, \mathrm{K}, \mathrm{Na}, \mathrm{Fe}$ 및 $\mathrm{S}$ 등의 원소를 함유하고 있으며 [8], 점토의 대체 원료로서 석탄회의 사용이 가능함을 알 수 있다.

본 연구에서 사용하는 $\mathrm{D}$ 사의 fly ash는 $\mathrm{SiO}_{2}, \mathrm{Al}_{2} \mathrm{O}_{3}$ 및 $\mathrm{Fe}_{2} \mathrm{O}_{3}$ 함유량이 $70 \mathrm{wt} \%$ 이하로 $10.22 \mathrm{wt} \%$ 의 $\mathrm{CaO}$ 를 함유하고 있어 ASTM 규정에 의해 $\mathrm{C}$ 급으로 분류할 수 있으며, bottom ash는 산화물 중 $\mathrm{SiO}_{2}, \mathrm{Al}_{2} \mathrm{O}_{3}$ 및 $\mathrm{Fe}_{2} \mathrm{O}_{3}$ 함유량이 $70 \mathrm{wt} \%$ 이상으로 $\mathrm{F}$ 급 석탄회임을 알 수 있다 [9]. $\mathrm{Na}_{2} \mathrm{O}$ 와 $\mathrm{MgO}$ 와 같은 알칼리 성분이 미량 첨가되어 있어 $\mathrm{F}$ 급 석탄회는 반응성이 낮은 실리케이트 결정을 형성하는데 반해 $\mathrm{CaO}$ 의 함유량이 많은 $\mathrm{C}$ 급 석탄회는 칼슘-알루미노실리케이트 결정체를 형성한다[2]. 따라서 본 실험에서 사용된 다량의 알칼리 성분을 함유한 $\mathrm{C}$ 급 fly ash에 비해 $\mathrm{F}$ 급의 bottom ash는 소결성이 감소함을 예측할 수 있다. 고온으로 가열할 경우, 융제 역할을 하 는 $\mathrm{Fe}_{2} \mathrm{O}_{3}$ 가 fly ash에는 $1.47 \mathrm{wt} \%$, bottom ash에는 3.24 $\mathrm{wt} \%$ 로서 함유되어 있음을 알 수 있었다.

$\mathrm{D}$ 사의 석탄회 강열감량은 fly ash가 $20.26 \mathrm{wt} \%$, bottom $\mathrm{ash}$ 가 $3.73 \mathrm{wt} \%$ 로서 fly ash와 같이 미연탄소량이 다량 으로 함유된 경우에는 강도의 감소가 예상되어 강도와 가소성을 부여하는 점토의 첨가가 요구된다. 강열감량 대부분은 미연탄소에 기인된 것으로 미연탄소량이 많으 면 강도저하가 초래되므로 $\mathrm{ASTM}$ 에서 $5.0 \sim 6.0 \%$ 이하 로 규정하고 있다[9].

석탄회와 점토의 X-선 회절 분석 결과 fly ash와 bottom ash는 quartz, illite, moscovite 등이 공통적으로 관찰되
었으며, fly ash 에서는 calcite 상이 보이고 있으며 이는 화학성분에서 $\mathrm{CaO}$ 성분이 높은것과 일치하고 있다. Clay 는 주결정상이 quartz상이고 일부 알칼리상이 관찰되었다.

\section{2. 소성온도와 조성에 따른 시편의 수축률과 결정상}

석탄회-점토계에서 석탄회의 첨가량에 따른 시편의 수 축 결과를 일정한 승온속도 하에서 연속적인 치밀화 과 정을 Fig. 1에 보인다. Fly ash-clay계 시편은 초기 수축 은 $800^{\circ} \mathrm{C}$ 부근에서 시작하고 있으며 bottom ash-clay계 시편은 $900^{\circ} \mathrm{C}$ 부근에서 시작되고 있다. 또한 Fly ashclay계 시편은 $900^{\circ} \mathrm{C}$ 부근의 온도에서 수축이 낮으며 $1000^{\circ} \mathrm{C}$ 부근에서 다시 급격하게 수축하는 것을 볼 수가 있다. 이는 석탄회에 포함된 미연탄소분의 분해반응에 의한 것으로 생각된다. 두 시편 모두 $1100^{\circ} \mathrm{C}$ 에서 급격 히 수축하는 것을 볼 수 있으며 이는 석탄회와 점토내의 알칼리 성분이 액상으로 되면서 치밀화가 급격하게 진행 하는 것으로 보인다.

소성 온도와 혼합조성에 따른 시편의 결정상의 변화를 조사하고자 $1150^{\circ} \mathrm{C}$ 에서 30 분간 열처리한 fly ash-clay계 시편과 bottom ash-clay계 시료의 X-선 회절 분석 결과 를 Fig. 2에 나타내었다. 주결정상은 quartz, anorthite, albite, mullite상이 관찰되고 석탄회의 첨가량이 증가함에 따라 quartz상의 피크 intensity가 감소 하였으며, anorthite 의 피크는 증가하는 것을 볼 수가 있다. 이는 $\mathrm{CaO}$ 성분 이 $\mathrm{SiO}_{2}$ 와 유리상의 $\mathrm{Al}_{2} \mathrm{O}_{3}$ 성분과 반응하여 anorthite상
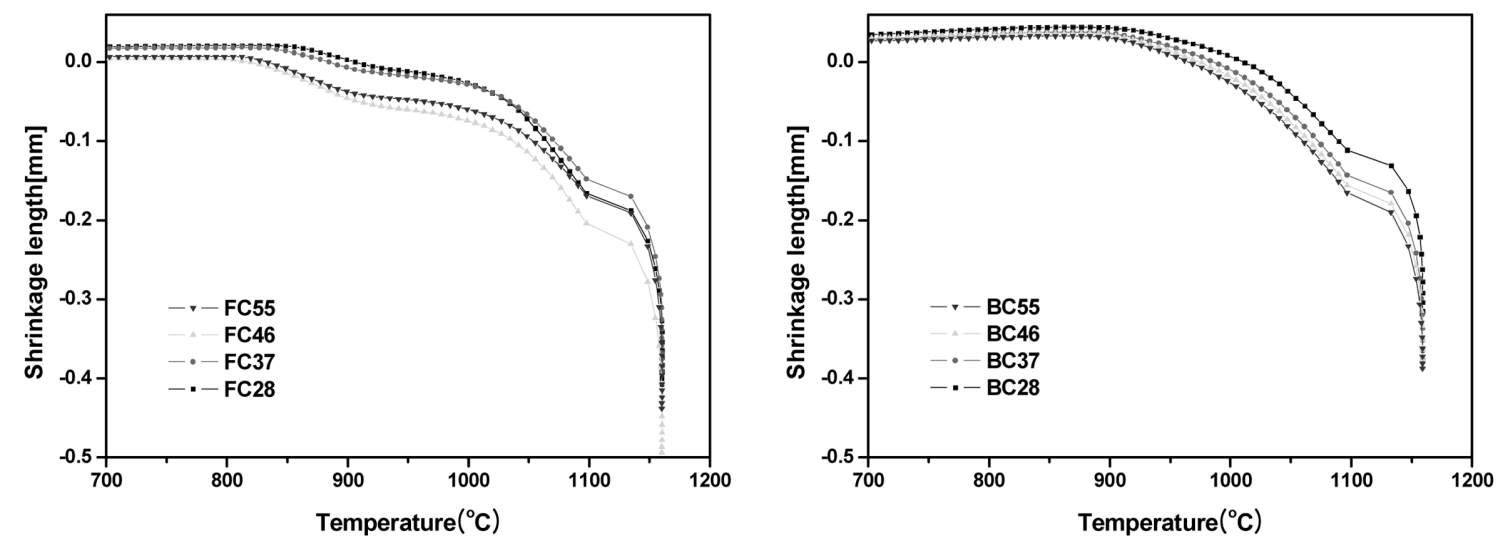

Fig. 1. Linear shrinkage as a function of temperature for the fly ash (bottom ash) - clay systems (heating rate, $10^{\circ} \mathrm{C} / \mathrm{min}$ ). 

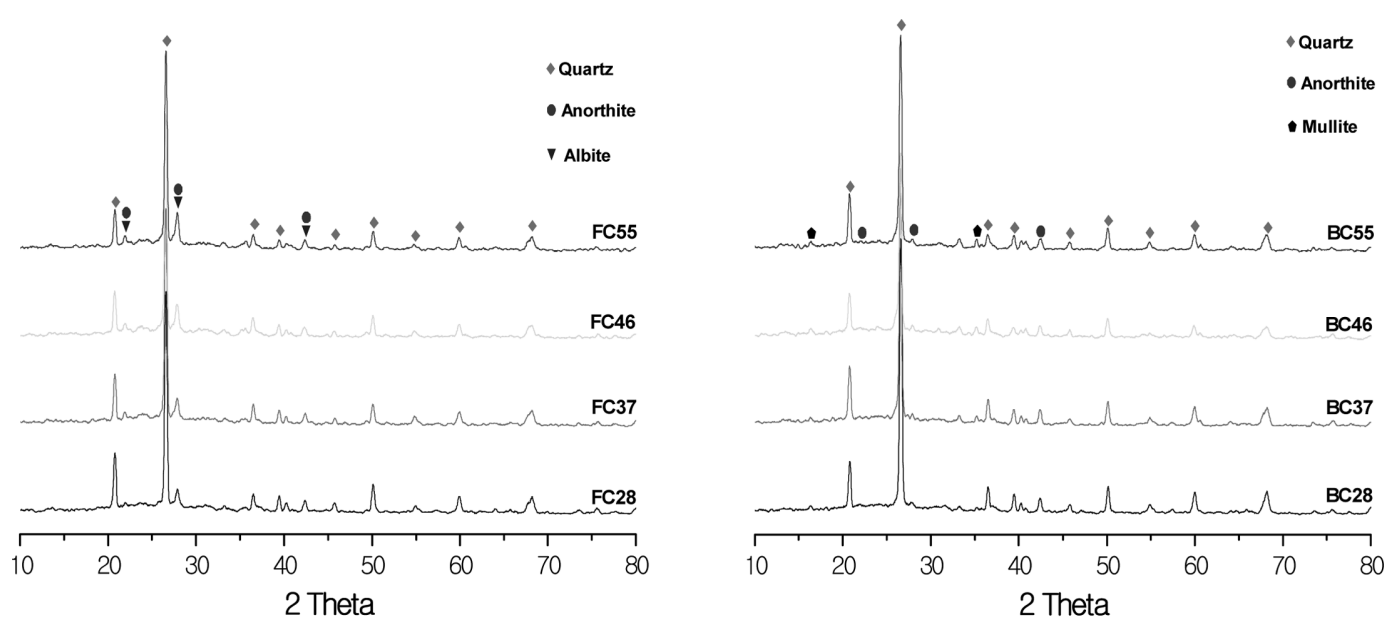

Fig. 2. XRD Patterns of coal ash-clay systems heated at $1,150^{\circ} \mathrm{C}$ for $30 \mathrm{~min}$.

이 생성되었기 때문이다[10].

\section{3. 조성에 따른 시편의 미세구조}

$1150^{\circ} \mathrm{C}$ 에서 소성된 시편의 미세구조를 Fig. 3 와 4 에 각각 나타내었다. 모든 시료에서 크고 작은 기공들이 관 찰되는데 이것은 원료물질인 석탄회의 미연탄소분과 $\mathrm{Fe}_{2} \mathrm{O}_{3}$ 의 화학 반응에 의해 발생된 $\mathrm{CO}_{2} \mathrm{gas}$ 의 팽창에 의 한 것으로 생각된다[11]. $50 \mathrm{wt} \%$ 의 석탄회가 첨가된 시
편은 가소성을 부여하는 점토의 첨가량이 작아 비교적 큰 기공들이 관찰되었으나, 점토의 첨가량이 증가함에 따라 치밀화가 진행되어 기공이 소멸되거나 크기가 감소 함을 관찰할 수 있다.

\section{4. 조성에 따른 시편의의 물리적 특성}

석탄회의 첨가량, 열처리 온도에 따른 시편의 물리적 특성을 Fig. 5와 6에 각각 나타내었다. Fig. 5는 조성과
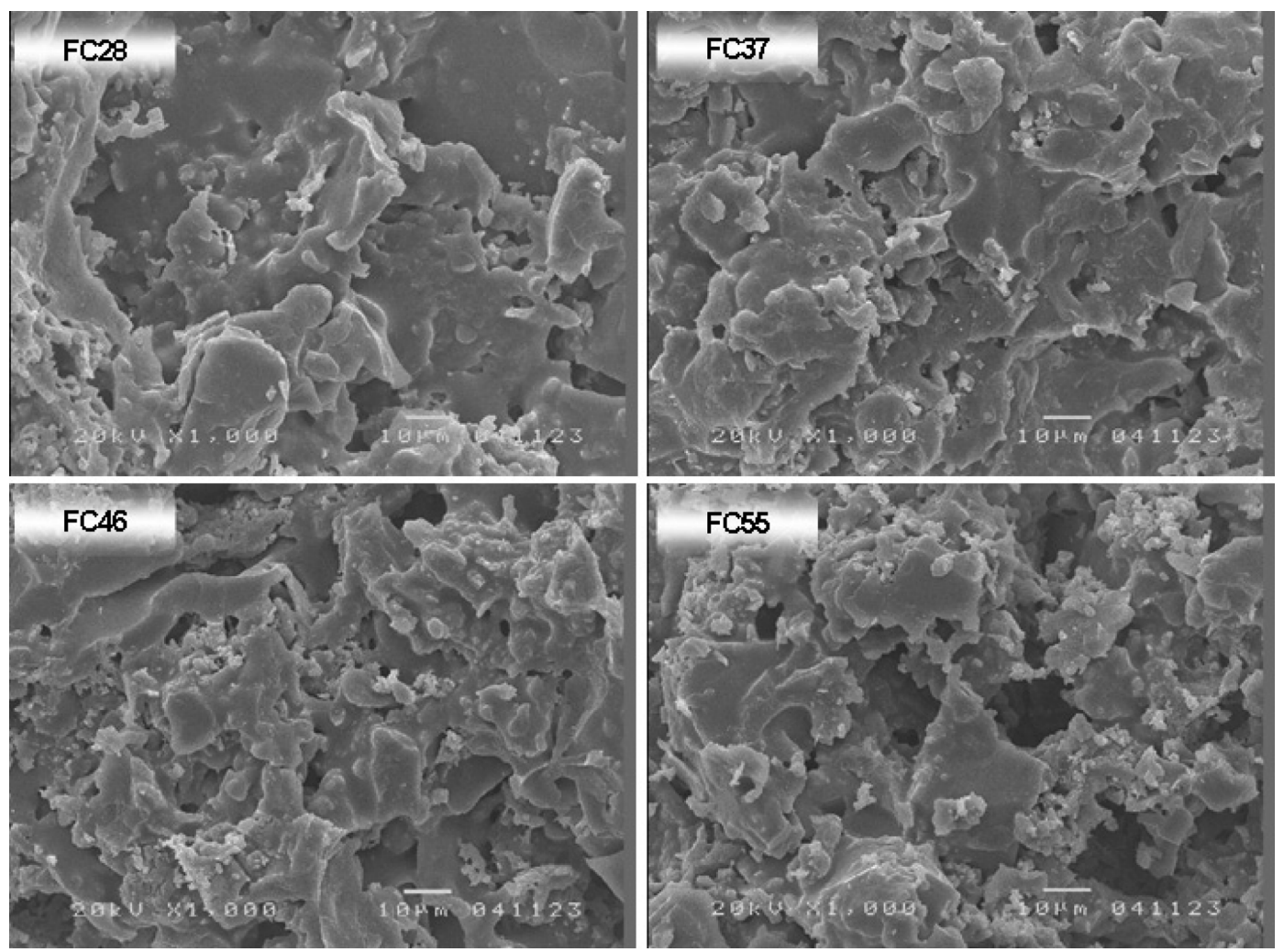

Fig. 3. SEM micrographs of the fly ash-clay systems sintered at $1150^{\circ} \mathrm{C}$. 

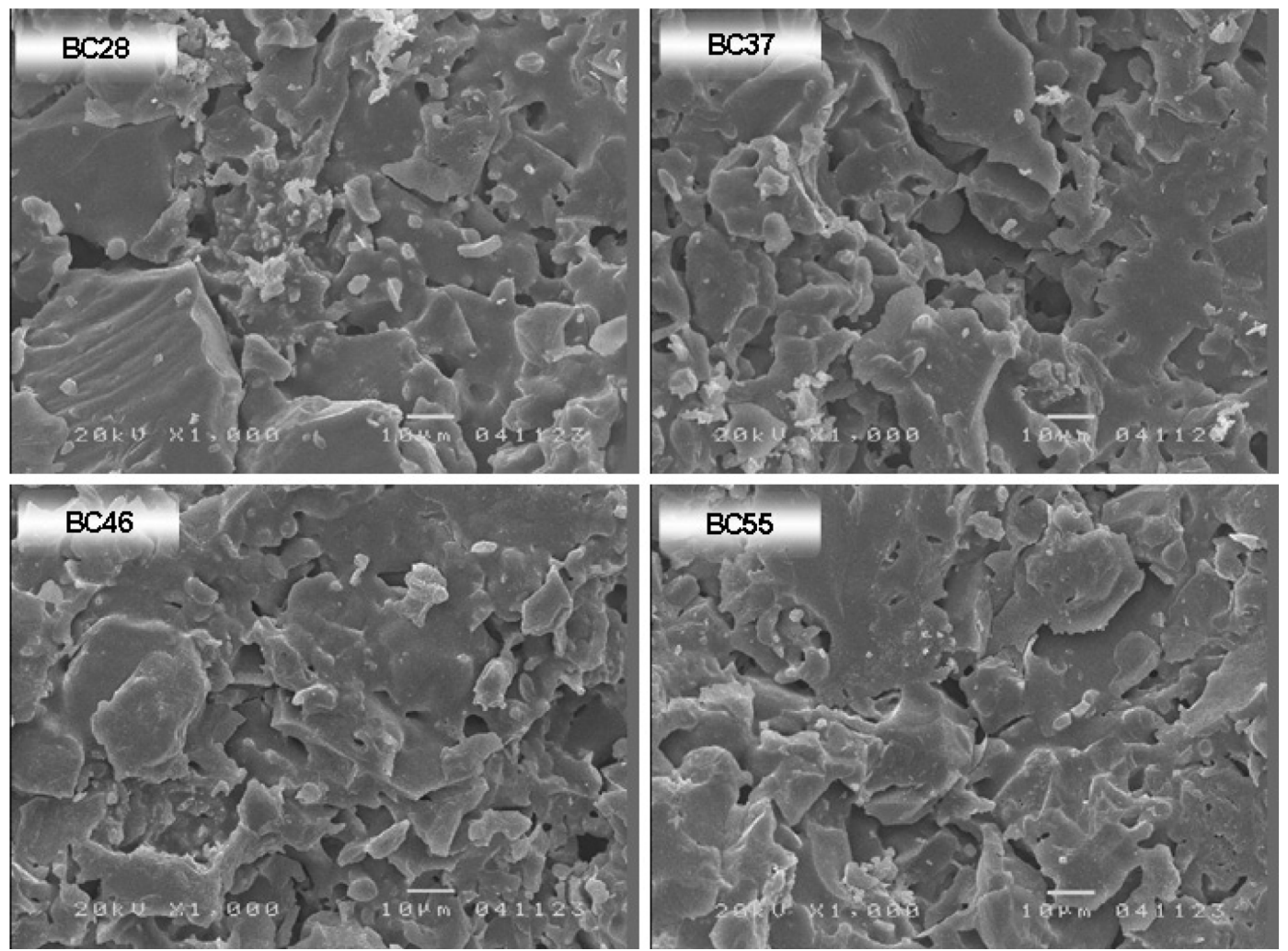

Fig. 4. SEM micrographs of the bottom ash-clay systems sintered at $1150^{\circ} \mathrm{C}$.
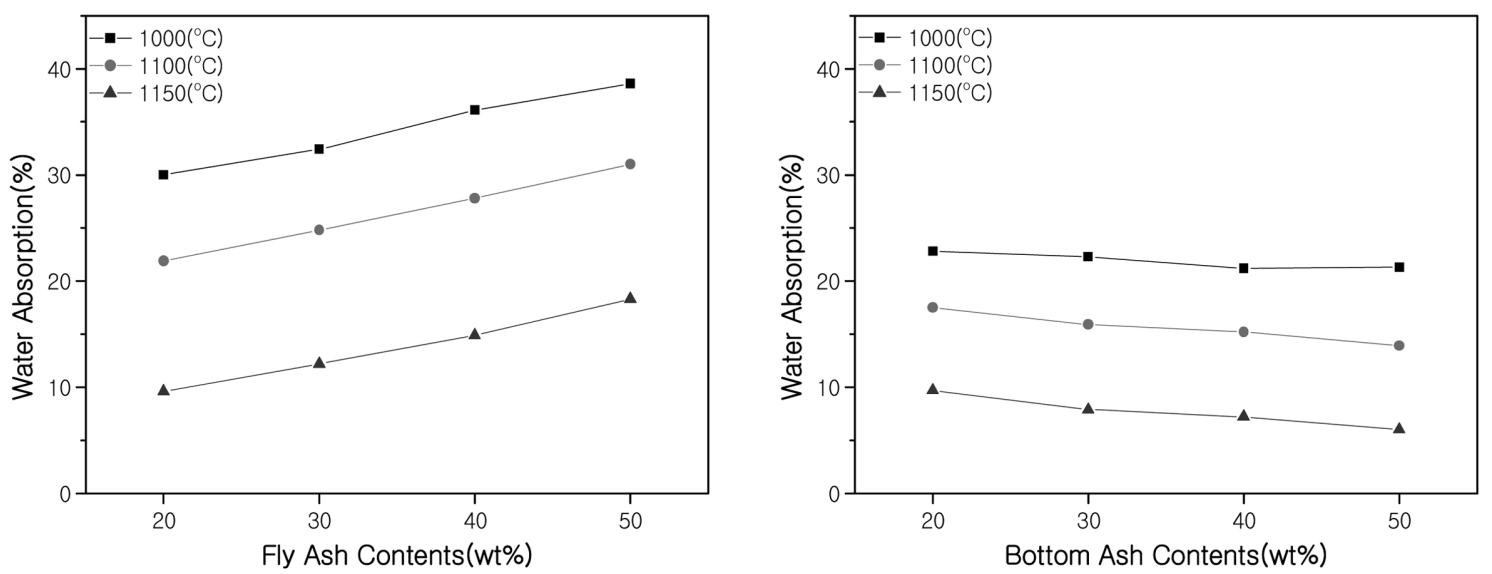

Fig. 5. Water absorption of the coal ash-clay systems.

열처리 온도에 따른 흡수율을 나타낸 것으로 점토의 첨 가량과 열처리 온도가 증가함에 따라 생성된 유리상에 의한 치밀화가 진행되어 기공의 크기와 분포가 감소하여 흡수율이 감소하였다. Bottom ash-clay계 시편에서 bottom $\mathrm{ash}$ 의 첨가량이 증가함에 따라 흡수율이 감소하는데 이 는 bottom ash의 성분 중 $\mathrm{Fe}_{2} \mathrm{O}_{3}$ 가 융제 역할을 하여 치 밀화에 기여하는 것으로 생각된다. 시료 중 $\mathrm{FC} 28$ 과 $\mathrm{BC} 55$ 가 $9.63 \%$ 와 $5.95 \%$ 로 낮은 흡수율을 나타내었다.

석탄회의 첨가량과 열처리 온도에 따른 압축강도 결
과를 Fig. 6에 나타내었다. 열처리 온도 증가에 따라 치밀화가 진행되어 압축강도는 상승하였다. Fly ashclay계 시편은 fly ash의 첨가량이 증가할수록 압축강도 가 감소하였으며 bottom ash의 경우 첨가량이 증가할 수록 압축강도가 증가였다. 이는 fly ash에 존재하는 다 량의 미연탄소분이 증가하기 때문으로 압축강도를 저하 시키는것으로 생각된다. 압축강도 측정결과 소성온도 $1150^{\circ} \mathrm{C}$ 에서 $\mathrm{FC} 28$ 과 $\mathrm{BC} 55$ 시편이 높은 압축강도를 나 타내었다. 


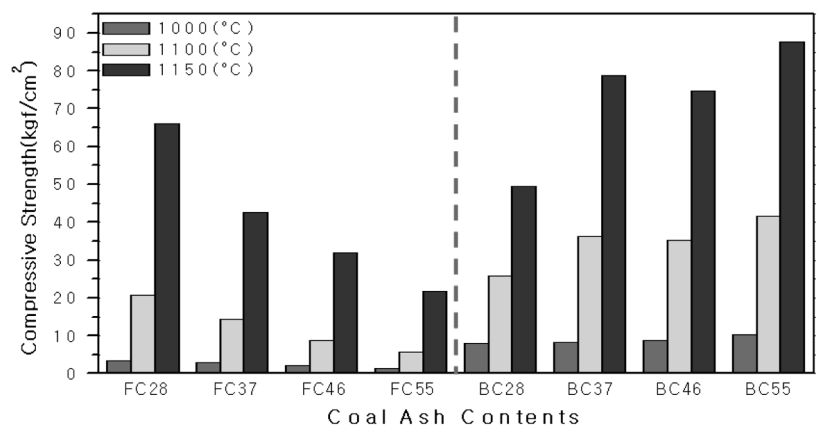

Fig. 6. Compressive strength for the coal ash-clay systems sintered at various temperatures with coals ash contents.

\section{4. 결 론}

본 연구에서는 흡수율 및 압축강도가 우수한 골재를 제조하기 위하여 저급 점토에 fly ash와 bottom ash를 첨가하여, 열처리 조건에 따른 물리·화학적 특성을 조사 하였다.

출발물질의 원료는 fly ash, bottom ash, clay를 이용 하였으며, 소성후 fly ash를 첨가한 시편의 주결정상은 quartz, anorthite, albite이며, bottom ash를 첨가한 시편 은 quartz, anorthite, mullite가 관찰되었다.

Fly ash-clay계 시편의 초기 수축은 $800^{\circ} \mathrm{C}$ 부근에서 시작하고 있으며 bottom ash-clay계 시편은 $900^{\circ} \mathrm{C}$ 부근 에서 시작되고 있다. 또한 fly ash-clay계 시편은 $900^{\circ} \mathrm{C}$ 부근에서 수축이 낮으며 $1000^{\circ} \mathrm{C}$ 에서 다시 급격하게 수 축하는 것을 볼 수가 있다. 이는 석탄회에 포함된 미연 탄소분의 분해반응에 의한 것으로 판단된다. 소성한 시 편의 흡수율은 fly ash 함량이 증가함에 따라 증가하였 으나, bottom ash의 함량이 증가함에 따라 낮아지는 것 을 알 수 있었다. 이는 bottom ash의 $\mathrm{Fe}_{2} \mathrm{O}_{3}$ 가 소성시 융제 역할을 한 것으로 생각된다. $1150^{\circ} \mathrm{C}$ 에서 소성한 시편 중 $\mathrm{FC} 28$ 과 $\mathrm{BC55}$ 시편에서 각각 흡수율과 압축강 도가 우수하였으며, $\mathrm{BC} 55$ 의 경우 흡수율 $5.95 \%$ 와 압
축강도 $87.5 \mathrm{kgf} / \mathrm{cm}^{2}$ 로 가장 우수하였다.

\section{참 고 문 헌}

[1] N.J. Kim, H.Y. Cho, S.K. Kim, S.W. Kang, S.H. Min and T.Y. Lee, "Removal of hydrogen sulfide using porous artificial aggregates made by coal fly-ash", J. Kor. Soc. of Environ. Eng. 28(4) (2006) 407.

[2] K.N. Kim, J.H. Kwon and D.Y. Shin, "The manufacturing of fly ash-clay system ceramic bricks", J. Kor. Solid Wastes Eng. Soc. 18(5) (2001) 459.

[ 3 ] H.Y. Park, S.I. Seo, S.C. Kim and D.S. Kang, "Reburning of bottom ash in a coal-fired power plant and its effect on the plant management", J. Kor. Solid Wastes Eng. Soc. 24(5) (2007) 472.

[ 4 ] J.T. Song, S.D. Yun, D.W. Ryou and K.S. Han, "Manufacture and properties of coal fly ash-clay body", J. of the Korean Ceramic Society 33(7) (1996) 771.

[5] Y.S. Chu, J.K. Lee and K.B. Shim, "Preparation of lightweight aggregate using glass abrasive sludge and effects of pores on the aggregate properties", J. Kor. Cera. Soc. 42(1) (2005) 37.

[6] KS F 2503, "Testing method for density and absorption of coarse aggregate", Korean Standards Association, Korea (2007).

[7] KS L 3305, "Testing method for compressive strength of insulating fire bricks", Korean Standards Association, Korea (2007).

[8] J.S. Shin, "Characterization and agricultural utilization of fly ash", Mineral and Industrial. 8(1) (1995) 10.

[9] ASTM C618-92a, "Standard specification for fly ash and raw or calcined natural pozzolan for use as mineral admixture in portland cement concrete", Am. Soc. for Testing and Mat., Annual Book of ASTM Standards, Volume 04.02, West Conshohocken, Pennsylvania (1994).

[10] J.T. Song, S.D. Yoon, M.S. Ahn and K.S. Han, "Mineral Compositions of the heated coal fly ash", J. Kor. Asso. of Crystal Growth 5(2) (1995) 178.

[11] H.J. Lee, D.W. Kim, K.G. Lee, Y.T. Kim, S.C. Hong and S.J. Lee, “Analysis of coal fly ash", J. Kor. Asso. of Crystal Growth 3(2) (1993) 185. 